\title{
THE RAISE OF EXCISE TAX RATES WILL HAMPER THE TAX MANEUVER
}

\section{D.Gordeev}

In 2013-2014, the government undertook a reform of the taxation system applied in the oil industry, which was called 'the tax maneuver' by the expert community. Essentially, the reform is aimed at equalizing the domestic and world prices of oil (less transport costs): the reduced rates of export duties and excise taxes on petroleum products will be offset by the correspondingly increased rate of the mineral extraction tax (MET) (the revenues generated by the new MET are expected to be approximately twice as high as the lost amount of export duty). As a result of the tax maneuver, the subsidizing of the domestic oil-refining sector, which is producing negative value added in terms of world prices, should be scaled down. When the domestic and world prices of oil and petroleum products become equal, the prices of the latter will soar in the domestic market, if excise taxes are not reduced by way of compensation. However, the excise taxes on petroleum products are continually being raised, and this may forestall the implementation of the entire reform in the nearest future.

On May 23, 2016, the law was adopted ${ }^{1}$ whereby from June 1, 2016 a new mechanism for distributing between different levels of this country's budget the excise tax payments generated by sales of motor gasoline, diesel fuel and motor oils produced in the territory of the Russian Federation. Earlier, in accordance with the established norms published in Annex 3 to the Federal Law 'On the Federal Budget for 2015 and Planning Period 2016 and 2017'2, all excise tax payments were to be transferred first to the federal budget, and then allocated in full to the budgets of RF subjects. Under the new mechanism, $88 \%$ of excise tax paymentes will be allocated to regional budgets, and the remaining $12 \%$ - to the federal budget. Besides, in 2016, the rates of excise taxes on motor gasoline and diesel fuel were raised twice ${ }^{3}$ in order to increase regional road funds ${ }^{4}$.

In connection with the alterations introduced into the excise tax allocation mechanism and the changes in excise rates for gasoline and diesel fuel, it would be of interest to analyze the resulting movement of the aggregate amount of excise tax receipts in the federal budget, as well as at their level in the budget of each region.

1 Federal Law of the Russian Federation No. 145-FZ of May 23, 2016.

2 Federal Law of the Russian Federation No.384-FZ of December 1, 2014 (as amended as of 28 November 2015).

3 From January 1, 2016, the excise rate for gasoline was increased by Rb 2 (thus amounting to $\mathrm{Rb} 7.53$ per liter), and of that for diesel fuel - by 70 kopecks (thus amounting to Rb 4.15 per liter). The second raise of the excise rates occurred on April 1, 2016. Growth amounted to Rb 2 per liter for gasoline fuel, and to $\mathrm{Rb} 1$ per liter for diesel fuel.

4 In accordance with Item 4 of Article 179.4 of the RF Budget Code (adopted by No. 145-FZ of 31 July 1998, as amended as of 3 July 2016), the budget revenues of a RF subject generated by excise taxes levied on motor gasoline, straight run gasoline, diesel fuel, motor oils for diesel and (or) carbureted (fuel injected) engines manufactured in RF territory, are to be allocated to the road fund of a given RF subject. 
Fig. 1 presents the movement of average retail prices of gasoline and diesel fuel in Russia (left-hand side axis) and of the ruble-denominated price of Brent $^{1}$ (right-hand side axis) in 2015-2016. Over the period from January through May 2016, prices of gasoline jumped by $5.7 \%$, and those of diesel fuel - by $3.1 \%$ on 2015.

In spite of rising prices of fuel, its sales over January-April 2016 increased on January-April 2015. Russia's total gasoline sales over January-April jumped by $1.1 \%$, and that of diesel fuel - by $2.8 \%$. Motor gasoline and diesel fuel sales across federal districts are shown in Fig. 2, pointing to rising diesel fuel consumption rates in the majority of federal districts. The total volume of diesel fuel sales in Russia over the period of January-April 2016 increased by $3 \%$ on the same period of 2015. The highest sales growth was observed in the Central Federal District $(+15 \%$, mostly due

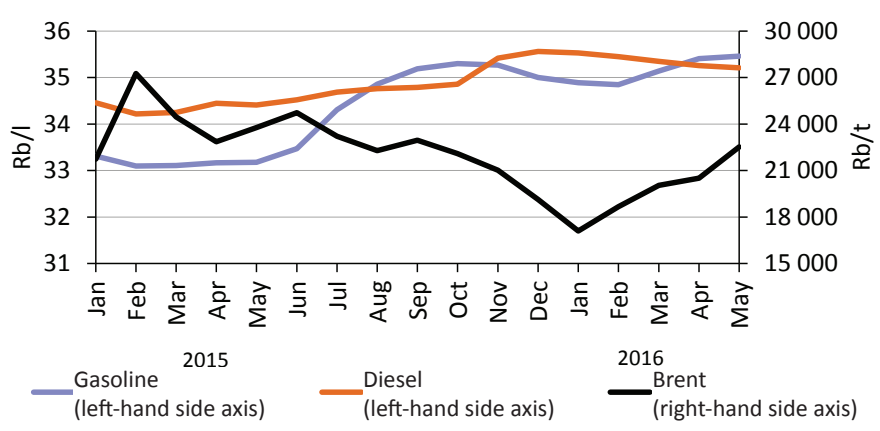

Source: Rosstat; RF Central Bank..

Fig. 1. Average consumer prices of gasoline and diesel fuel in Russia and price of Brent in 2015-2016

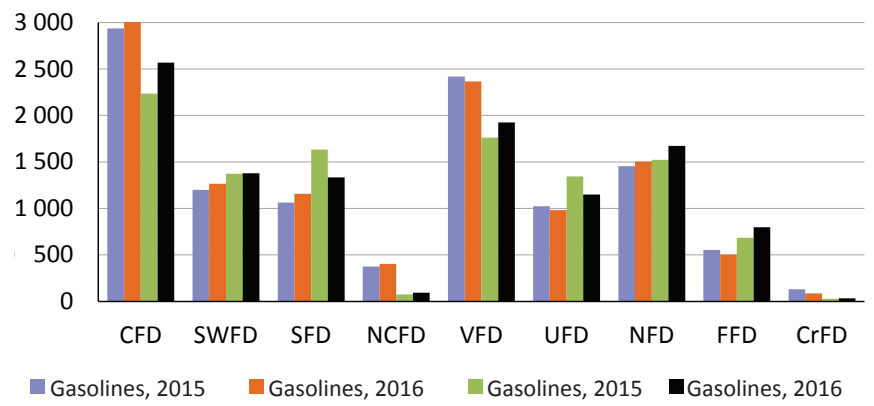

Source: Joint Economic and Social Data Archive.

Fig. 2. Sales of petroleum products in Russia, by federal district, over January-April 2015 and 2016, thousand $t$

Table 1

\section{THE GASOLINE AND DIESEL FUEL EXCISE TAX RECEIPTS IN THE BUDGETS OF REGIONS, BY FEDERAL DISTRICT, M RB}

\begin{tabular}{|c|c|c|c|c|c|}
\hline $\begin{array}{l}\text { Federal } \\
\text { district }\end{array}$ & $\begin{array}{c}\text { January- } \\
\text { April } 2015\end{array}$ & $\begin{array}{l}\text { Regional budget revenue } \\
\text { share generated by } \\
\text { excise taxes on fuel over } \\
\text { January-April } 2015, \%\end{array}$ & $\begin{array}{l}\text { January- } \\
\text { April } 2016\end{array}$ & $\begin{array}{l}\text { Regional budget revenue } \\
\text { share generated by } \\
\text { excise taxes on fuel over } \\
\text { January-April 2016, \% }\end{array}$ & $\begin{array}{l}\text { Ratio of revenue generated } \\
\text { by excise taxes on fuel } \\
\text { over January-April } \\
2016 \text { to that generated } \\
\text { over January-April } 2015, \%\end{array}$ \\
\hline $\begin{array}{l}\text { Russian } \\
\text { Federation }\end{array}$ & $102,501.9$ & 2.8 & $144,521.7$ & 4.5 & 141.0 \\
\hline \multicolumn{6}{|l|}{ including } \\
\hline CFD & $25,019.6$ & 2.1 & $37,060.3$ & 3.1 & 148.1 \\
\hline SWFD & $11,804.9$ & 3.1 & $16,909.4$ & 4.3 & 143.2 \\
\hline SFD & $11,903.8$ & 5.4 & $15,797.2$ & 6.9 & 132.7 \\
\hline NCFD & $2,466.4$ & 1.8 & $3,830.1$ & 2.7 & 155.3 \\
\hline VFD & $20,324.7$ & 3.9 & $28,636.1$ & 5.4 & 140.9 \\
\hline UFD & $10,663.3$ & 2.8 & $13,384.6$ & 3.6 & 125.5 \\
\hline NFD & $13,830.7$ & 3.4 & $20,237.1$ & 5.1 & 146.3 \\
\hline FFD & $5,630.0$ & 1.5 & $7,785.6$ & 2.4 & 138.3 \\
\hline CrFD & 858.5 & 2.5 & 881.2 & 2.5 & 102.6 \\
\hline
\end{tabular}

Source: own calculations based on the Joint Economic and Social Data Archive's statistics.

1 Average monthly quotes of Brent, recalculated in Russian rubles at an average monthly exchange rate. 
to Moscow Oblast's indices), the Volga Federal District $(+10 \%)$, and the Siberian Federal District $(+10 \%)$. In the Southern and Ural Federal Districts, diesel fuel sales lost $19 \%$ and $14 \%$ respectively.

As demonstrated by our calculations, over the period of JanuaryApril 2016, the revenues generated for regional budgets by excise taxes on gasoline and diesel fuel amounted to $\mathrm{Rb} 144.5 \mathrm{bn}$, which is $41 \%$ more than the index for the corresponding period of 2015. Detailed statistics describing the movement of excise tax payments can be seen in Table 1 .

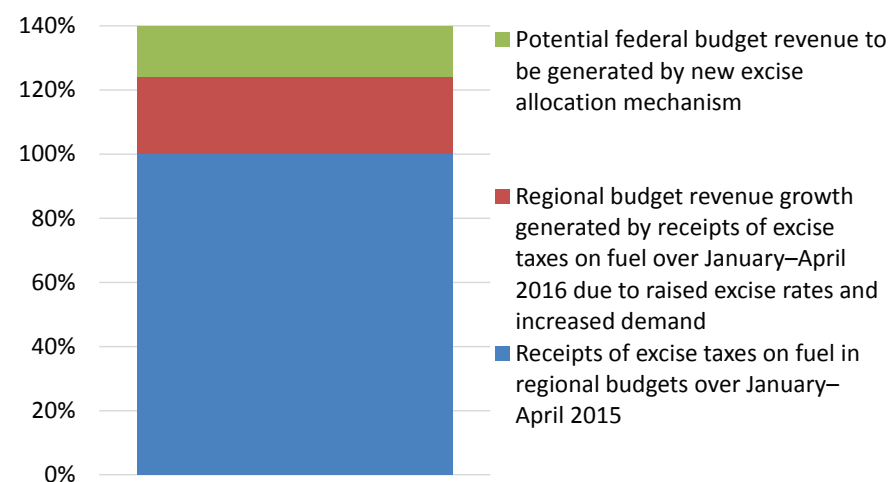

Fig. 3. Model calculations describing the receipts of excise taxes on gasoline and diesel fuel over January-April 2016 (under the tax regime introduced from 1 June 2016), compared with the corresponding period of 2015

introduction of the new excise

tax allocation mechanism from 1 June 2016 will result in reallocation to the federal budget of $12 \%$ of the revenues that used to be received by regional budgets.

If the new excise tax allocation mechanism had been introduced from January 2016, the structure of excise tax receipts in regional budgets and the federal budget by comparison with that in 2015 would have appeared to be as shown in Fig. 3.

As seen from Fig. 3, growth of regional budget revenue generated by the raised excise rates and increased sales would have amounted to $24 \%$, in spite of the transfer of $12 \%$ of excise tax receipts to the federal budget.

The existence of any further potential for increasing the amount of excise tax receipts is by no means certain, because the ongoing tax maneuver has come into conflict with the recently undertaken measures. These measures are being implemented in order to replenish the budget, but they preclude the development of a consistent strategy for reforming the oil industry.

Here is what we mean. Beside its fiscal function, export duty on oil is applied in order to bring down the domestic price of oil and thus subsidize the domestic economy ${ }^{1}$. Export duties and excises levied on petroleum products are indirect consumption taxes on spending abroad and in the domestic market. The tax maneuver undertaken by the government is designed to equalize the business conditions for oil companies operating in the domestic and foreign markets in order to boost the efficiency of domestic oil refineries that create negative value added ${ }^{2}$. It is necessary to note that the reduced excise rates for petroleum products suggested in the initial versions of the tax maneuver were designed to prevent growth of domestic prices of petroleum products as a result of the increased MET rate for oil. However, what we are observing now is exactly the opposite. In response to the increased MET rate for oil, the ruble-denominated amount of tax per tonne of oil has likewise increased, while the subsidizing of the domestic oil-refining sector has not been reduced, because the export duty on oil stays at the same level.

1 Idrisov G.I., Sinelnikov-Murylev S.G. Oil Export Duty: Cancel or Preserve. Neft Rossii, 2011, No. 12, December.

2 Idrisov G.I., Sinelnikov-Murylev S.G. Modernization or Conservation: the Role of Export Duties on Oil and Oil Products. Economic Policy, 2012, No. 3, pp. 5-19. 
Higher oil production costs will slash the profits of oil companies while keeping the prices in the domestic market at the same level. As a result, vertically integrated oil companies will try to compensate for the loss of their profit by increasing the prices of petroleum products. The reduction of excise rates for petroleum products, initially planned as part of the tax maneuver with the purpose of keeping their prices at the same level, did not take place. In April 2016 , the export duty on gasoline amounted to $\mathrm{Rb} 2,227$ per tonne, while the excise rate for gasoline was $\mathrm{Rb} 10,130$ per tonne. In other words, today we are faced with the situation where the domestic oil-refining sector is being subsidized through lower prices of oil, while at the same time the amount of tax denominated in rubles per tonne of petroleum products in the domestic market in much higher than the amount of tax per tonne levied on exported petroleum products.

As seen from our analysis, by raising the excise rates for gasoline and diesel fuel, it became possible to significantly boost the amount of their receipts in regional budgets. In spite of the rising average retail prices of petroleum products, no decline in their sales has been observed across the economy. The raised excise rates coupled with the new excise allocation mechanism will generate an additional federal budget revenue of Rb 20bn in 2016. At the same time, raising the excise rates is a dubious tool to be applied for the purpose of replenishing the budget, because it is contrary to the policy behind the tax maneuver. If we have in mind the goal of additionally replenishing the federal budget, it would be more reasonable ${ }^{1}$ to speed up the tax maneuver while gradually reducing the excise and export duty rates, and to raise the mineral extraction tax, thus generating an additional budget revenue ${ }^{2}$. As a result, the market would receive clear pricing signals without any misbalances between the rates of export duty and excise taxes, while the amount of tax receipts in the budget will be determined by the rate of a single MET. In addition, this will conduce to modernization of domestic oil refineries, to be translated into their higher efficiency. Meanwhile, the situation today is exactly the opposite: the tax maneuver has been postponed indefinitely. The policy of raising MET and keeping the export duty rate for oil unchanged while increasing the excise rates for petroleum products is contrary to the tax maneuver's logic. It means that we are moving in a direction that is clearly perpendicular to that of the tax maneuver, if not directly opposite to it. Besides, there has emerged a peculiar situation where the share of taxes per tonne of petroleum products denominated in rubles, levied by the Russian government on domestic consumers, is higher than that levied on foreign ones. For an oil rich country, this situation is almost paradoxical.

1 Bobylev Yu., Idrisov G., Kaukin A., Rasenko O. Oil, budget and tax maneuver. Online Monitoring of Russia's Economic Outlook, No. 15 (November 2015), pp. 11-14.

2 Idrisov G.I., Kaukin A.S. Tax maneuver: economic growth acceleration to the detriment of budget consolidation. Russian Economic Developments, 2016, No. 6, pp. 7-11. 